\begin{tabular}{cc|c}
\hline Tar. Bil. Der. & Journal of Agricultural Sciences \\
& $\begin{array}{c}\text { Dergi web sayfası: } \\
\text { www.agri.ankara.edu.tr/dergi }\end{array}$ & Journal homepage: \\
& www.agri.ankara.edu.tr/journal
\end{tabular}

\title{
Bisküvi Üretiminde Tam Buğday Unu ve Paçallarının Kullanımı
}

\author{
Mustafa Kürşat DEMIR ${ }^{a}$ \\ ${ }^{a}$ Necmettin Erbakan Üniversitesi, Mühendislik ve Mimarlık Fakültesi, Gıda Mühendisliği Bölümü, Köyceğiz Kampüsü Yerleşkesi, Meram, \\ 42090, Konya, TÜRKIYY
}

ESER BILGISII

Araştırma Makalesi

DOI: 10.1501/Tarimbil_0000001311

Sorumlu Yazar:Mustafa Kürşat DEMİ, E-posta: mkdemir@konya.edu.tr, Tel: +90 (332) 3252265 / 4019

Geliș Tarihi: 06 Șubat 2014, Düzeltmelerin Geliși: 02 Nisan 2014, Kabul: 09 Haziran 2014

\begin{abstract}
ÖZET
Bu çalışmada, farklı oranlarda tam buğday unu ikamesi ile bisküvi üretimi amaçlanmıştır. Bu amaçla; Gerek-79 buğday örnekleri, laboratuvar tipi çekiçli değirmende öğütülerek tam buğday unu elde edilmiştir. Tam buğday unları da, altı farklı oranda (\% 0, 20, 40, 60, 80 ve 100), bisküvilik unlara ikame edilerek, bisküvi üretiminde kullanılmıştır. Üretilen bisküvilerde de, sertlik, renk (L*, a* ve b*), fiziksel (çap, kalınlık ve yayılma oranı), kimyasal, besinsel (nem, ham kül, ham protein, ham lif, fitik asit ve toplam fenolik madde) ve duyusal (tat, renk, koku, görünüş ve genel beğeni) özellikleri araştırılmıştır. Tam buğday unu ikamesi ile deskriptif olarak bisküvilerin çap ve yayılma oranlarının azaldığ 1 , kalınlık değerlerinin ise arttığ 1 tespit edilmiştir. Ayrıca, bisküvilerin L* ve b* değerlerinin azaldığ $\mathrm{b}^{*}$ * ve sertlik değerlerinin ise arttığı belirlenmiştir. Kimyasal özellikler bakımından da, tam buğday unu miktarının artmasıyla, bisküvilerin nem, ham protein, ham kül, ham lif, fitik asit ve toplam fenolik madde içeriklerinin arttığ tespit edilmiştir. Ayrıca, tam buğday unu ilavesinin, bisküvilerin duyusal özelliklerine olumsuz bir etki yapmadığı belirlenmiştir. Sonuç olarak; kontrol grubu örneklerle kıyaslandığında, bisküvilerin fiziksel özelliklerin korunması için \% 20 oranına kadar tam buğday unu ikamesinin yapılması, kimyasal ve duyusal özelliklerin geliştirilmesi için de \% 60 oranından daha fazla ikame gerektiği tespit edilmiştir.
\end{abstract}

Anahtar Kelimeler: Gerek-79; Tam buğday unu; Bisküvi; Bisküvi kalitesi

\section{Utilization of Whole Wheat Flour and Its Blends in Cookies Production}

\section{ARTICLE INFO}

Research Article

Corresponding Author: Mustafa Kürşat DEMIR, E-mail: mkdemir@konya.edu.tr, Tel: +90 (332) 3252265 / 4019

Received: 06 January 2014, Received in Revised Form: 02 April 2014, Accepted: 09 June2014

\begin{abstract}
In this study, it was aimed to produce cookie with substitution of whole wheat flour at different ratios. For this purpose, Gerek-79 wheat samples were milled using on laboratory type hammer mill in order to obtain whole wheat flour. The cookie flour samples that were replaced with whole wheat flour at six different ratios $(0,20,40,60,80$ and $100 \%)$ were used in cookie production. Hardness, colour ( $\mathrm{L}^{*}, \mathrm{a}^{*}$ and $\mathrm{b}^{*}$ ), physical (diameter, thickness and spread ratio), chemical, nutritional (moisture, crude ash, crude protein, crude fiber, phytic acid and total phenolic content) and sensory properties (taste, colour, odour, appearance and overall acceptability) of cookie samples were investigated. Whole wheat flour
\end{abstract}


substitution increased thickness values of the cookie samples, but decreased diameter and spread ratio descriptively. Also, whole wheat flour substitution decreased $\mathrm{L}^{*}$ and $\mathrm{b}^{*}$ values of the cookie samples, but increased a* and hardness values. In terms of chemical properties, higher amounts of whole wheat flour increased moisture, crude protein, crude ash, crude fiber, phytic acid, total phenolic contents of cookies. Also, addition of whole wheat flour did not negatively affect the sensory characteristics of cookies. In conclusion, it has been found that, for maintaining physical properties of cookies whole wheat flour should be added up to $20 \%$, and for improving chemical and sensory properties of cookies more than $60 \%$ of cookie flour should be substituted by whole wheat flour.

Keywords: Gerek-79; Whole wheat flour; Cookie; Cookie quality

(C) Ankara Üniversitesi Ziraat Fakültesi

\section{Giriş}

Bisküvi hemen hemen her toplumda çokça tüketilen, ayaküstü yenilebilen ve tüketici açısından çikolataya oranla daha sağlıklı bulunan lezzetli unlu mamüllerden birisidir. Besin kalitesinin iyi, doyurucu ve ucuz olması bunun temel nedenlerini oluşturmaktadır (Sudha et al 2007b; Beğen 2012). Ayrica bayatlamadan uzun süre saklanabilmesi, tüketiciye hoş ve değişik lezzetlerde sunulabilmesi nedeniyle tüketimi gün geçtikçe artmakta ve ögün dışı beslenmede önemli yer tutmaktadır (Beğen 2012).

Günümüzde, daha sağlıklı bir hayat için tüketicilerin tercihleri düşük kalorili, yüksek lifli, düşük şeker ve tuz içerikli ve daha az katkılı gıdalar yönünde olmaktadır (Meuser et al 1994). Tam tahıllı gidalar, son yıllarda tüketici talepleri doğrultusunda üretimi ve tüketimi artan gıdaların başında gelmektedir (Collar 2008).

Buğday tanesi, yaklaşık \% 8 kabuk, \% $6-7$ aleuron, \% 3 ruşeym ve \% 82 unsu endosperm tabakalarından ibarettir (Elgün \& Ertugay 1995). Un değirmenciliğinin amac1 ise, maksimum oranda endosperm ayrışımını sağlayarak, kepek ve ruşeym gibi yan ürünlerin una karışmasının engellemektir. Çünkü öğütme prosesinde, ekstraksiyon oranına bağlı olarak bu yan ürünler una karıştıkça, son ürünün depolama stabilitesini ve pişme kalitesini etkilemektedir. $\mathrm{Bu}$ nedenle tanenin yaklaşık \% 18'lik kısmını oluşturan bu kepekli fraksiyonlar, değirmen teknolojilerinde ayrıştırılmaktadır. Fakat bu ayrıştırılma sonucunda, buğday unlarında önemli besinsel kayıplar meydana gelmektedir. Örneğin; buğday tanesinin \% 3'lük kısmını oluşturan ruşeym, buğday ununa göre, daha fazla protein (3 kat), yağ (7 kat), şeker (15 kat), mineral madde (6 kat) içeriğine sahiptir (Elgün \& Ertugay 1995; Srivastava et al 2007; Sudha et al 2007a).

Dünya nüfusunun yaklaşık \% 35 'inin temel besini olan ve tüm dünyada besinlerden alınan kalorinin yaklaşık \% 20'sini sağlayan buğday (Balkan \& Gençtan 2008) insan beslenmesinin vazgeçilmez unsurlarındandır (Akgün et al 2011). Tam buğday unu ise, buğday tanesinin kepek ve ruşeym kısımlarıyla birlikte bir bütün olarak öğütülmesi ile elde edilir (Elgün \& Demir 2008). Tam buğday unu; besinsel lif, mineral maddeler, B kompleks vitaminler, antioksidanlar (fitik asit, glutatiyon ve tokoferol vb.) ve esansiyel amino asitler bakımından oldukça zengin bir kaynaktır. Aynı zamanda iyi azot dengesine sahip olan proteini ve yüksek nişasta içeriği ile uygun ve çok ucuz bir enerji kaynağıdır. Kalp hastalıkları, yüksek tansiyon, kolon kanseri, diyabet ve obezite riskini azaltıcı etkilerinden dolayı tam buğday ununa olan talep yıldan yıla artış göstermektedir (Elgün \& Demir 2008; Slavin 2000).

Yapılan bilimsel araştırmalarda tam buğday ununun çeşitli firıncılık ürünlerinde kullanılmasına yönelik çalışmalar yoğunluktadır. Bu çalışmalarda hem ürünün besleyici değerinin arttırılması hedeflenmiş, hem de teknolojik olarak karşılaşılan problemlere çözümler aranmıştır (Uzunkaya \& Ercan 1999). Ancak, farklı katkılarla birlikte tam buğday ununun özellikle ekmekler ve çeşitlerinde, kullanım olanakları çokça araştırılmış; diğer tahıl ürünlerinden kullanımı konusunda yapılan çalışmaları ise sınırlı kalmıştır (Yavaş 2012). 
$\mathrm{Bu}$ araştırmada; ülkemizde günden güne kullanımı yaygınlaşan tam buğday ununun ekmek dışında farklı bir tahıl ürünü olan bisküvi üretiminde kullanım imkanlarının araştırılması hedeflenmiş̧ir. Çalışmamızın amacı ise; bisküvilik buğday unlarına belirli oranlarda $(\% 0,20,40,60,80$ ve 100$)$ tam buğday unu ikame edilerek hazırlanan un paçalların, bisküvi üretimi için uygunluğunun belirlenmesi, değerlendirilmesi ve bisküvi kalitesi üzerine etkilerinin incelenmesidir.

\section{Materyal ve Yöntem}

\subsection{Materyal}

Araştırmada materyal olarak bisküvilik un, Gerek-79 buğday çeşidi, şeker, yağsız süt tozu, mısır şurubu, sodyum bikarbonat, amonyum bikarbonat, şortening ve tuz kullanılmıştır. Bisküvilik un, sodyum bikarbonat ve amonyum bikarbonat ticari bir bisküvi fabrikasından (Şimşek Bisküvi ve Gıda Sanayi A.Ş, Karaman, Türkiye), Gerek-79 buğday1 Konya Ticaret Borsası laboratuvarlarından (KLD A.Ş., Konya, Türkiye), diğer hammaddeler ise piyasadan temin edilmiştir.

\subsection{Bisküvilik tam buğday unlarının elde edilmesi}

Gerek-79 buğday çeşidi, \% 15 su esasına göre tavlanmış ve laboratuvar tipi çekiçli değirmende (Perten, LM 3100, Perten Instruments AB, Huddinge, İsveç) $500 \mu$ göz açıklığı bulunan elek kullanılarak, öğütülmüştür. Öğütme sonunda da, tam buğday unları (\% 100) elde edilmiştir.

\subsection{Bisküvi örneklerinin hazırlanması}

Bisküvi hamurları, AACC Standart Metot No: 10-54.01'e (AACC 2000) göre hazırlanmıştır. Deneme desenine göre, farklı formülasyonlarda hazırlanan bisküvilerde ise, tam buğday unu $\% 0,20,40,60,80$ ve 100 oranlarında bisküvilik un ile yer değiştirerek kullanılmıştır. Paçallarda kullanılan tam buğday unu oranındaki artışlara bağlı olarak, formülasyondaki tüm materyaller, $100 \mathrm{~g}$ un esasına göre, $13-17 \mathrm{~mL}$ arasında değişen su ile laboratuvar tipi bir mikserde (Kenwood KMX-50, Kenwood Ltd., United Kingdom) hamur oluşana kadar karıştırılmıştır. Elde edilen hamur, $5 \mathrm{~mm}$ yüksekliğinde inceltilmiş, $50 \mathrm{~mm}$ çapında dairesel şekil verilerek laboratuvar tipi bir firında (LG MP-9485S, Seoul, Korea) pişirilmiştir. Pişirme süre $(17 \mathrm{dk})$ ve sicaklıkları $\left(170^{\circ} \mathrm{C}\right)$ ise AACC metodu modifiye edilerek gerçekleştirilmiştir. Soğutulduktan sonra da, tüm bisküvi örnekleri kilitli polietilen ambalajda muhafaza edilmiştir.

\subsection{Un analizleri}

Denemelerde kullanılan unların; su (AACC 4419.01), ham protein (AACC 46-12.01), ham kül (AACC 08-01.01), ham lif (AACC 32-10.01) ve ham yağ (AACC 30-25.01) miktarları ACCC (2000)'de belirtildiği şekilde tespit edilmiş ve sonuçlar kuru madde esasına göre hesaplanmıştır. Ayrıca renk okumaları, Hunter Lab Color Quest II Minolta CR400 (Konica Minolta Sensing, Inc., Osaka, Japan) cihazı kullanılarak, $\mathrm{L}^{*}$ değeri [ (0) siyah-(100) beyaz ], a* değeri [ $(+)$ kırmızı- $(-)$ yeşil ] ve $b^{*}$ değeri $[(+)$ sarı-(-) mavi ] cinsinden ölçülmüştür (Francis 1998). Fitik asit değerleri, kolorimetrik metot kullanılarak, Haug \& Lantzsch (1983)'e göre belirlenmiş olup, sonuçlar mg $100 \mathrm{~g}^{-1}$ cinsinden verilmiştir. Toplam fenolik madde içeriği ise, Folin-Ciocaltaeu metodu kullanılarak spektrofotometrik yöntemlerle tayin edilmiş olup, sonuçlar kuru madde üzerinden gram ekstrede $\mu$ g gallik asite ( $\mu$ g GAE g ${ }^{-1}$ ) eşdeğer olacak şekilde hesaplanmıştır (Singleton \& Rossi 1965). Zeleny sedimantasyon tayini ICC-Standart No: 116/1 metoduna göre (ICC 2002), yaş gluten miktarı ile gluten indeks değeri ise AACC 38-12.02 metoduna göre (AACC 2000) belirlenmiştir.

\subsection{Bisküvi analizleri}

Bisküvi örneklerinin çap ve kalınlık değerleri, AACC Standart Metot No: 10-54.01 (AACC 2000)'de belirtildiği şekilde dijital kumpas (0.001 mm, Mitutoyo, Tokyo, Japan) kullanılarak ölçülmüştür. Bisküvilerin çap (mm) ve kalınlık (mm) değerleri belirlendikten sonra, yayılma oranı; bisküvi çaplarının (mm) kalınlıklarına $(\mathrm{mm})$ oranlanmasıyla elde edilmiştir. Bisküvi örneklerinin tekstür özelliklerinin belirlenmesinde tekstür analiz cihazı (TA-XT plus, Stable Micro systems, UK) kullanılmış olup, 3 nokta kırılma testi (three point bend rig) tekniğine göre 
kırılma kuvveti (sertlik) değerleri (N) tespit edilmiştir (Load cell: $30 \mathrm{~kg}$, ön-test hızı: $1.0 \mathrm{~mm} \mathrm{~s}^{-1}$, test hızı: $3.0 \mathrm{~mm} \mathrm{~s}^{-1}$, son-test hızı: $10.0 \mathrm{~mm} \mathrm{~s}^{-1}$, uzaklık: $5 \mathrm{~mm}$, trigger kuvveti: $50 \mathrm{~g}$ ). Ayrıca renk, nem, ham kül, ham protein, ham lif, fitik asit ve toplam fenolik madde içerikleri 2.4 'de belirtildiği şekilde belirlenmiştir.

Duyusal değerlendirme; Necmettin Erbakan Üniversitesi Gıda Mühendisliği Bölümü öğretim elemanları ve yüksek lisans öğrencilerinden oluşturulan, yaşları 21-55 arasında değişen ve konu ile ilgili kısa bir eğitime tabi tutulan 10 kişilik panelist grubu tarafindan gerçekleştirilmiş̧ir. Bisküvi örnekleri; tat, renk, koku, görünüş ve genel beğeni özellikleri bakımından, $5^{\prime}$ lik hedonik skala ile değerlendirilmiştir (5 Puan: Çok iyi, 4 Puan: İyi, 3 Puan: Kabul edilebilir, 2 Puan: Yeterli değil, 1 Puan: Kötü).

\subsection{Istatistiki analizler}

Denemeler 2 tekerrürlü olarak yürütülmüş olup, araştırma sonucunda elde edilen veriler varyans analizine tabi tutulmuş; farklılıkları istatistiki olarak önemli bulunan ana varyasyon kaynaklarının ortalamaları ise, Duncan çoklu karşılaştırma testi ile karşılaş̧tırılmıştır. İstatistiki analiz sonuçları, tablolar halinde özetlenmiş ve şekiller üzerinde tartışılmıştır (Düzgüneş et al 1987).

\section{Bulgular ve Tartışma}

\subsection{Analitik sonuçlar}

Bisküvi yapımında kullanılan unlara ait bazı analiz sonuçları, Çizelge 1'de verilmiştir. Bisküvi yapımında kullanılan tam buğday unlarının, rafine bisküvilik unlara göre; daha yüksek ham protein, ham yağ, ham kül ve ham life sahip oldukları belirlenmiştir. $\mathrm{Bu}$ da, tam buğday unlarının zengin kimyasal kompozisyonu ile son ürünün besinsel kalitesinin arttırılması açısından, daha uygun un paçalı olduğunu göstermiştir.

\subsection{Araştırma sonuçlart}

\subsubsection{Bisküvilerin fiziksel, tekstürel ve renk özellikleri}

Çap, kalınlık ve yayılma oranı değerleri, bisküvinin teknolojik kalitesinin belirlenmesi açısından önemli parametreler olup, genellikle çapın geniş, yayılma

\section{Çizelge 1- Bisküvilik un ve tam buğday unlarının kalite karakteristikleri}

Table 1-Quality characteristics of cookie flour and whole wheat flour

\begin{tabular}{|c|c|c|}
\hline Hammadde & Bisküvilik un & Tam buğday unu \\
\hline \multicolumn{3}{|l|}{ Renk } \\
\hline $\mathrm{L}^{*}$ & $91.71 \pm 0.72$ & $87.75 \pm 0.19$ \\
\hline$a^{*}$ & $-0.62 \pm 0.05$ & $0.97 \pm 0.02$ \\
\hline$b^{*}$ & $8.29 \pm 0.16$ & $11.13 \pm 0.12$ \\
\hline \multicolumn{3}{|l|}{ Kimyasal Özellikler } \\
\hline Nem $(\%)$ & $11.71 \pm 0.33$ & $10.30 \pm 0.09$ \\
\hline Ham kül $(\%)^{1}$ & $0.672 \pm 0.01$ & $1.425 \pm 0.03$ \\
\hline Ham protein $(\%)^{1,2}$ & $9.01 \pm 0.14$ & $11.57 \pm 0.18$ \\
\hline Ham yağ $(\%)^{1}$ & $0.46 \pm 0.08$ & $1.80 \pm 0.11$ \\
\hline Ham lif $(\%)^{1}$ & $0.24 \pm 0.02$ & $2.09 \pm 0.10$ \\
\hline Su aktivitesi (aw) & $0.656 \pm 0.01$ & $0.360 \pm 0.01$ \\
\hline Fitik asit $\left(\mathrm{mg} 100 \mathrm{~g}^{-1}\right)^{1}$ & $308.26 \pm 8.63$ & $1136.12 \pm 21.69$ \\
\hline Toplam fenolik madde $\left(\mu \mathrm{g} \mathrm{GAE} \mathrm{g}^{-1}\right)^{1}$ & $817.58 \pm 15.18$ & $1478.15 \pm 27.99$ \\
\hline \multicolumn{3}{|l|}{ Fizikokimyasal Özellikler } \\
\hline Yaş gluten $(\%)^{1}$ & $23.5 \pm 0.49$ & $26.9 \pm 0.28$ \\
\hline Gluten indeks $(\%)^{1}$ & $81.4 \pm 2.90$ & $72.2 \pm 2.33$ \\
\hline Zeleny sedimantasyon $(\mathrm{cc})^{3}$ & $20.5 \pm 0.71$ & $17.0 \pm 1.41$ \\
\hline
\end{tabular}

\footnotetext{
${ }^{1}$, sonuçlar kuru madde esasına göre verilmiştir; ${ }^{2}$, protein $=\mathrm{N} \times 5,70 ;{ }^{3}, \% 14$ su üzerinden verilmiştir
} 
oranının yüksek, kalınlığın ise düşük olması istenir (Kissell et al 1971). Ancak aşırı yayılma da pratikte çok istenmez. Bisküvi üretiminde tam buğday unu ikame oranında artışa gidilmesi ile ortalama çap değerlerinde deskriptif olarak bir azalma meydana gelmiştir (Çizelge 2). En yüksek çap değerleri kontrol grubu bisküvi örneklerinde (61.92 \pm 1.42 $\mathrm{mm})$, en düşük çap değerleri ise \% 100 tam buğday unu kullanılan bisküvi örneklerinde $(59.55 \pm 1.17$ $\mathrm{mm}$ ) elde edilmiştir. Bisküvilerin ortalama kalınlık ve yayılma oranı değerleri üzerinde ise tam buğday ununun belli bir seviyede etkisinin olduğu, \% 40 ve üzerinde kullanımı ile bu değerlerin istatistiki olarak değişmediği belirlenmiştir. Jeltema et al (1983) farklı kepeklerin (yulaf, soya ve buğday) bisküvi kalitesine etkisini inceledikleri çalışmalarında, kepek ilavesi ile yayılma oranlarının azaldığını bildirmişlerdir. Levent (2005)'de, farkl1 lif kaynaklarını ve buğday kepeğini kullandığı bisküvi çalışmasında, lif oranlarında artışa gidildiğinde yayılma oranının azaldığını bildirmiştir.

Bisküvinin deformasyona karşı gösterdiği direnç olarak tanımlanan sertlik ve dayanıklılık gibi tekstürel özellikleri, firın ürünlerinde oldukça önemli parametrelerdir (Ahlborn et al 2005). Üretilen bisküvilerde, tam buğday unu ikamesi ile sertlik ölçüm değerleri de artmıştır (Çizelge 2). Ajila et al (2008) bisküvi formülasyonunda mango lifi kullanılması ile artan sertlik değerlerinin, lif ilaveli bisküvi hamurlarının yüksek su içeriğinden kaynaklanmış olabileceğini rapor etmişlerdir. Sudha et al (2007b)'da, kepek ilave edilmeyen bisküvilere göre, \% 20 oranında buğday, pirinç, yulaf ve arpa kepekleri ilave edilmiş bisküvilerin, sertlik değerlerinin sirasılyla \% $14.7, \% 31.6, \% 3.6$ ve $\% 28.7$ oranlarında arttığını belirlemişlerdir.

Çizelge 2'de verilen renk ölçüm değerlerine bakıldığında; tam buğday unu ikamesiyle üretilen bisküvilerin $\mathrm{L}^{*}$ (parlaklık) ve $\mathrm{b}^{*}$ (sarılık) değerlerinin azaldığı, $a^{*}$ (kırmızılık) değerlerinin ise $\operatorname{arttığ} 1$ tespit edilmiştir. En yüksek parlaklık ve sarılık değerleri, kontrol grubu örneklerde tespit edilmiştir. Çap, kalınlık ve yayılma oranı özelliklerinde olduğu gibi, \% 20 tam buğday unu ikamesi, kontrol grubuna eş değerde bisküviler vermiştir. Genel olarak, tam buğday unu ikamesi ve ikame oranlarında artışa gidilmesi, son ürün renginde değişimlere sebep olmuş, daha mat, daha kırmızı renkli bir ürün eldesini mümkün kılmıştır. Jeltema et al (1983) yapmış oldukları çalışmalarında, bisküvi üretiminde buğday kepeği kullanımın son ürün rengini etkilediğini, daha koyu ve daha az sarı ürünlerin elde edildiğini bildirmişlerdir. Benzer bir başka çalışmada da, buğday kepeği ilavesi ile bisküvilerin a değerlerinin arttığ 1 , b değerlerinin ise düştüğü tespit edilmiştir (Özkaya \& Demir 1999).

\subsubsection{Bisküvilerin kimyasal ve besinsel özellikleri}

Tam buğday ikamesi ile üretilen bisküvi örneklerinin nem, ham kül, ham protein, ham lif, fitik asit ve toplam fenolik madde miktarına ait veriler Çizelge 3 'te verilmiştir. Bisküvi nem içeriklerinin \% 4.254.86 arasında değiş̧iği ve tam buğday unu oranında artışa gidilmesiyle de nem içeriklerinin arttığ 1 tespit edilmiştir. Levent (2005) yapmış olduğu çalışmasında; lif katkısının bisküvi nem içeriklerini bariz bir şekilde arttırdığını, kabarma düzeyi düşük, sert yapılı ürünlerin en yüksek nem içeriğine sahip olduğunu belirlemiştir. Su tutmada, higroskopik özelliğe sahip selüloz, pentozan ve şekerlerin etkili olduğu bilinmektedir (Jeltema et al 1983). Tam buğday unu da, selüloz, pentozan ve şekerler bakımından zengin olan kepekli fraksiyonları içerisinde barındırdığı için (Demir 2010), bisküvilerin nem içerikleri artmıştır. Ayrıca, bisküvi formülasyonunda tam buğday unu miktarında artışa gidilmesi, son ürünlerin ham protein ve ham lif değerlerini de arttırmıştır. Bu artışa sebep olarak, tam buğday ununun ham protein ve ham lif miktarlarının (\% 11.57 ve \% 2.09), rafine bisküvilik una göre (\% 9.01 ve \% 0.24) daha yüksek olması gösterilebilir (Çizelge 1). En yüksek ham kül değerleri ise \% 100 tam buğday unu ile üretilen bisküvilerde $(\% 1.70 \pm$ $0.02)$ elde edilmiş olup, bunu sirasıyla $\% 80(\% 1.62$ $\pm 0.01), \% 60(\% 1.56 \pm 0.01), \% 40(\% 1.50 \pm 0.02)$ ve $\% 20(\% 1.45 \pm 0.01)$ tam buğday unu paçalı içeren örnekler izlemiştir. Levent (2005), farklı lif kaynaklarını (limon, elma, buğday lifi) ve buğday kepeğini kullandığ 1 çalışmasında; lif oranlarında artışa gidildiğinde, bisküvilerin kül ve selüloz değerlerinin arttığı bildirmiştir. 
Çizelge 2- Bisküvilerin fiziksel, sertlik ve renk özelliklerine tam buğday ununun etkisi ${ }^{1}$

Table 2-Influence of whole wheat flour on the physical, hardness and colour properties of cookies

\begin{tabular}{cccccccc}
\hline \multirow{2}{*}{ Ornek $^{2}$} & \multirow{2}{*}{$\begin{array}{c}\text { Çap } \\
\text { (mm) }\end{array}$} & $\begin{array}{c}\text { Kalınlı } \\
(\text { mm })\end{array}$ & $\begin{array}{c}\text { Yaylma } \\
\text { oranı (Çap) } \\
\text { Kalınlı) }\end{array}$ & $\begin{array}{c}\text { Sertlik } \\
(N)\end{array}$ & \multicolumn{3}{c}{ Renk } \\
\cline { 7 - 9 } & & & $L^{*}$ & $a^{*}$ & $b^{*}$ \\
\hline Kontrol (\% 0 TBU) & $61.92 \pm 1.42 \mathrm{a}$ & $5.27 \pm 0.35 \mathrm{c}$ & $11.80 \pm 0.80 \mathrm{a}$ & $44.01 \pm 1.24 \mathrm{f}$ & $72.28 \pm 0.27 \mathrm{a}$ & $7.10 \pm 0.72 \mathrm{c}$ & $28.46 \pm 0.33 \mathrm{a}$ \\
$\% 80 \mathrm{U}: \% 20 \mathrm{TBU}$ & $60.72 \pm 0.81 \mathrm{ab}$ & $5.85 \pm 0.77 \mathrm{~b}$ & $10.57 \pm 1.54 \mathrm{a}$ & $47.19 \pm 0.22 \mathrm{e}$ & $71.72 \pm 0.89 \mathrm{a}$ & $7.64 \pm 0.41 \mathrm{bc}$ & $27.92 \pm 0.07 \mathrm{a}$ \\
$\% 60 \mathrm{U}: \% 40 \mathrm{TBU}$ & $60.65 \pm 1.34 \mathrm{abc}$ & $6.70 \pm 0.43 \mathrm{a}$ & $9.09 \pm 0.62 \mathrm{~b}$ & $49.60 \pm 0.50 \mathrm{~d}$ & $71.02 \pm 0.10 \mathrm{ab}$ & $7.99 \pm 0.08 \mathrm{abc}$ & $26.48 \pm 0.11 \mathrm{~b}$ \\
$\% 40 \mathrm{U}: \% 60 \mathrm{TBU}$ & $60.48 \pm 0.95 \mathrm{bc}$ & $6.73 \pm 0.50 \mathrm{a}$ & $9.03 \pm 0.67 \mathrm{~b}$ & $52.95 \pm 0.16 \mathrm{c}$ & $69.82 \pm 1.07 \mathrm{bc}$ & $8.27 \pm 0.49 \mathrm{ab}$ & $25.88 \pm 0.42 \mathrm{bc}$ \\
$\% 20 \mathrm{U}: \% 80 \mathrm{TBU}$ & $60.33 \pm 0.86 \mathrm{bc}$ & $6.85 \pm 0.39 \mathrm{a}$ & $8.83 \pm 0.48 \mathrm{~b}$ & $56.04 \pm 0.34 \mathrm{~b}$ & $68.52 \pm 0.25 \mathrm{c}$ & $8.45 \pm 0.30 \mathrm{ab}$ & $25.68 \pm 0.29 \mathrm{c}$ \\
$\% 100 \mathrm{TBU}$ & $59.55 \pm 1.17 \mathrm{c}$ & $7.00 \pm 0.50 \mathrm{a}$ & $8.55 \pm 0.73 \mathrm{~b}$ & $59.38 \pm 0.55 \mathrm{a}$ & $65.66 \pm 0.46 \mathrm{~d}$ & $8.97 \pm 0.29 \mathrm{a}$ & $24.64 \pm 0.06 \mathrm{~d}$ \\
\hline
\end{tabular}

${ }^{1}$, aynı harfle işaretlenmiş ortalamalar istatistiki olarak birbirinden farklı değildir $(\mathrm{P}<0.05){ }^{2}, \mathrm{U}$, bisküvilik un; TBU, tam buğday unu

\section{Çizelge 3- Bisküvilerin bazı kimyasal ve besinsel özelliklerine tam buğday ununun etkisi ${ }^{1,2}$}

Table 3-Influence of whole wheat flour on the some chemical and nutritional properties of cookies

\begin{tabular}{ccccccc}
\hline Ornek & $\begin{array}{c}\text { Nem } \\
(\%)\end{array}$ & $\begin{array}{c}\text { Ham kül } \\
(\%)\end{array}$ & $\begin{array}{c}\text { Ham protein } \\
(\%)\end{array}$ & $\begin{array}{c}\text { Ham lif } \\
(\%)\end{array}$ & $\begin{array}{c}\text { Fitik asit } \\
\left(m g ~ 100 g^{-1}\right)\end{array}$ & $\begin{array}{c}\text { Toplam fenolik } \\
\text { madde } \\
\left(\mu g \text { GAE } g^{-1}\right)\end{array}$ \\
\hline Kontrol $(\% 0 \mathrm{TBU})$ & $4.25 \pm 0.06 \mathrm{e}$ & $1.38 \pm 0.02 \mathrm{f}$ & $5.40 \pm 0.05 \mathrm{e}$ & $0.22 \pm 0.01 \mathrm{f}$ & $211.79 \pm 9.39 \mathrm{f}$ & $713.68 \pm 5.83 \mathrm{f}$ \\
$\% 80 \mathrm{U}: \% 20 \mathrm{TBU}$ & $4.39 \pm 0.05 \mathrm{~d}$ & $1.45 \pm 0.01 \mathrm{e}$ & $5.47 \pm 0.02 \mathrm{de}$ & $0.56 \pm 0.03 \mathrm{e}$ & $323.70 \pm 4.31 \mathrm{e}$ & $813.46 \pm 27.99 \mathrm{e}$ \\
$\% 60 \mathrm{U}: \% 40 \mathrm{TBU}$ & $4.50 \pm 0.02 \mathrm{~cd}$ & $1.50 \pm 0.02 \mathrm{~d}$ & $5.53 \pm 0.06 \mathrm{~cd}$ & $0.88 \pm 0.01 \mathrm{~d}$ & $406.15 \pm 4.99 \mathrm{~d}$ & $1036.95 \pm 12.83 \mathrm{~d}$ \\
$\% 40 \mathrm{U}: \% 60 \mathrm{TBU}$ & $4.56 \pm 0.04 \mathrm{bc}$ & $1.56 \pm 0.01 \mathrm{c}$ & $5.59 \pm 0.05 \mathrm{bc}$ & $1.29 \pm 0.04 \mathrm{c}$ & $532.42 \pm 3.28 \mathrm{c}$ & $1084.78 \pm 15.16 \mathrm{c}$ \\
$\% 20 \mathrm{U}: \% 80 \mathrm{TBU}$ & $4.65 \pm 0.04 \mathrm{ab}$ & $1.62 \pm 0.01 \mathrm{~b}$ & $5.66 \pm 0.04 \mathrm{ab}$ & $1.67 \pm 0.03 \mathrm{~b}$ & $654.41 \pm 3.85 \mathrm{~b}$ & $1139.21 \pm 17.49 \mathrm{~b}$ \\
$\% 100 \mathrm{TBU}$ & $4.86 \pm 0.06 \mathrm{a}$ & $1.70 \pm 0.02 \mathrm{a}$ & $5.73 \pm 0.04 \mathrm{a}$ & $1.96 \pm 0.05 \mathrm{a}$ & $706.33 \pm 5.64 \mathrm{a}$ & $1333.01 \pm 11.66 \mathrm{a}$ \\
\hline
\end{tabular}

${ }^{1}$, aynı harfle işaretlenmiş ortalamalar istatistiki olarak birbirinden farklı değildir $(\mathrm{P}<0.05){ }^{2}$, sonuçlar kuru madde üzerinden verilmiştir; ${ }^{3}$, U, bisküvilik un; TBU, tam buğday unu

Hububatta doğal bir bileşen olarak bulunan fitik asit, insan beslenmesinde gerekli olan çinko, demir, kalsiyum ve magnezyum gibi minerallerle kompleks oluşturarak, bunların biyoyararlılığını düşüren ve de besleyici kaliteyi olumsuz yönde etkileyen anti-besinsel bir öğedir (Özkaya 2004). Diğer taraftan, fitik asitin antioksidan özelliği bulunmaktadır (Graf et al 1987). Bilgiçli et al (2007), farklı lif kaynakları ve buğday kepeği ile ürettikleri bisküvilerde, fitik asit miktarlarının $162.8 \pm 3.96$ ile $714.2 \pm 6.79 \mathrm{mg} 100 \mathrm{~g}^{-1}$ arasında değişim gösterdiğini bildirmişlerdir. Çalışmamızda elde edilen sonuçlara göre, bisküvi örneklerinin fitik asit miktarları $211.79 \pm 9.39$ ile $706.33 \pm 5.64 \mathrm{mg} 100 \mathrm{~g}^{-1}$ arasında değişim göstermiştir. En düşük fitik asit miktarı kontrol grubu örneklerde tespit edilmiş iken, artan tam buğday unu oranı fitik asit miktarını arttırmıştır (Çizelge 3). Fitatın önemli bir kısmı alöron tabakasında, çok az bir kısmı da embriyoda bulunmakla birlikte, una karışan kepek miktarı arttıkça bu undaki fitik asit miktarı da artmaktadır (Özkaya 2004). Bu bilgiler 1şında, tam buğday unu ilavesi ile son ürün olan bisküvilerin fitik asit miktarlarının artması da doğaldır.

Fenolik bileşenler birçok bitkide, tahıllarda ve diğer hububat ürünlerinde önemli miktarda bulunan, antioksidan aktiviteye sahip bileşikler olup, özellikle de tanenin dış kısımlarına yakın kepek tabakalarında yoğunlaşmaktadır (Beta et al 2005). Çizelge 3'e göre; toplam fenolik madde içeriği, $713.68 \pm 5.83$ ile $1333.01 \pm 11.66(\mu \mathrm{g}$ 


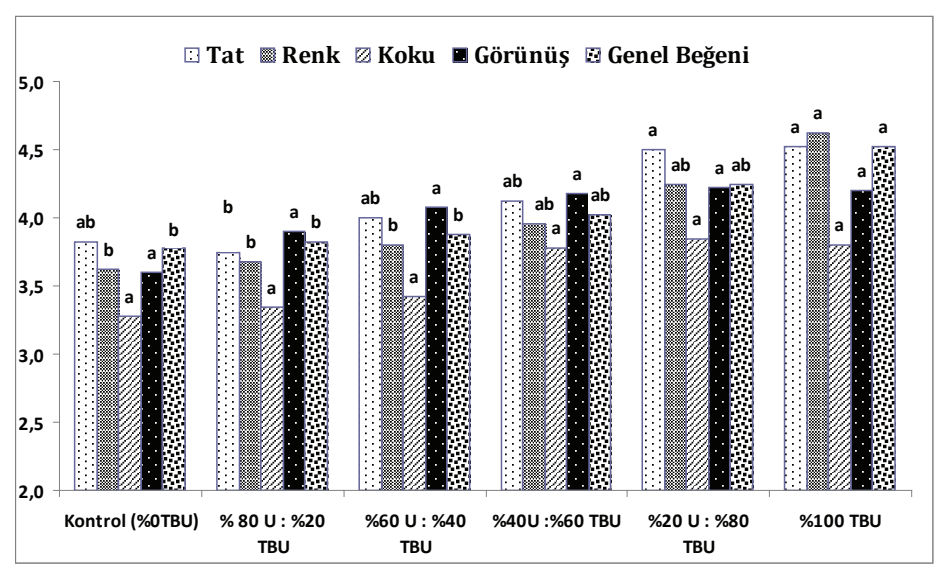

Şekil 1- Tam buğday unu ve paçallarını içeren bisküvi örneklerinin duyusal analiz özellikleri (U, bisküvilik un; TBU, tam buğday unu)

Figure 1-Sensory analyses properties of cookie samples containing whole wheat flour and its blends (U, cookie flour; TBU, whole wheat flour)

GAE $\mathrm{g}^{-1}$ ) arasında değişim göstermiştir. Bisküvi üretiminde kullanılan tam buğday unu miktarında artışlara gidilmesi, toplam fenolik madde miktarlarını da arttırmıştır. Özellikle de buğdayın dış kısımlarında yoğunlaşan fenolik bileşikler (Demir 2010) bunda etkili olmuştur.

\subsubsection{Bisküvilerin duyusal özellikleri}

Bisküvi örneklerinin 1-5 puan skalası ile değerlendirmeye tabi tutulan bazı duyusal özelliklerine ait verileri Şekil 1'de gösterilmiştir. Elde edilen bu verilere göre, tam buğday unu kullanımının duyusal parametreler açısından olumsuz bir etkiye sahip olmadığı, hatta \% 60'nın üzerinde kullanımının tat, renk, genel beğeni değerlerini arttırdığı ve daha beğenilir hale geldiği belirlenmiştir.

\section{Sonuçlar}

Bu çalışmada, bisküvilik buğday unlarına belirli oranlarda $(\% 0,20,40,60,80$ ve 100$)$ tam buğday unu ikame edilerek hazırlanan un paçalların bisküvi üretiminde kullanılma imkanları incelenmiş olup; 1) Bisküvi üretiminde fiziksel özelliklerin korunması açısından en ideal oranın \% 20 tam buğday unu ikamesinin olduğu, 2) Tam buğday unu ikamesiyle daha mat ve daha kırmızı renge sahip bisküvilerin elde edildiği, 3) Bisküvi formülasyonda tam buğday unu miktarında artışa gidilmesi ile, nem, ham protein, ham kül, ham lif, fitik asit ve toplam fenolik madde içeriklerinin arttığı, 4) Tam buğday unu kullanımının duyusal özellikler açısından olumsuz bir etkiye sahip olmadığı tespit edilmiştir. Elde edilen bu veriler 1şığında, toplumun her kesimi tarafından her ögünde sevilerek tüketilen bisküvi ve benzeri ürünlerde, rafine buğday unlarının yerine, besinsel açıdan üstünlüğü ispatlanan tam buğday unlarının tercih edilmesi gerektiği kanısına varılmıştır.

\section{Teşekkür}

$\mathrm{Bu}$ araştırma; Necmettin Erbakan Üniversitesi, Bilimsel Araştırma Projeleri Koordinatörlüğünce (Proje No: 131219005) desteklenmiştir.

\section{Kaynaklar}

AACC (2000). American Association of Cereal Chemists, Approved Methods of the AACC The Association: St. Paul, MN

Ahlborn G J, Pike O A, Hendrix S B, Hess W M \& Huber C S (2005). Sensory, mechanical and microscopic evaluation of staling in low-protein and gluten free breads. Cereal Chemistry 82(3): 328-335 
Ajila C M, Leelavathi K \& Prasada Rao U J S (2008). Improvement of dietary fiber content and antioxidant properties in soft dough biscuits with the incorporation of mango peel powder. Journal of Cereal Science 48(2): $319-326$

Akgün İ, Altındal D \& Kara B (2011). Isparta ekolojik koşullarında ekmeklik ve makarnalık bazı buğday çeşitlerinin uygun ekim zamanlarının belirlenmesi. Tarım Bilimleri Dergisi-Journal of Agricultural Sciences 17(4): 300-309

Balkan A \& Gençtan T (2008). Bazı ekmeklik buğday (Triticum aestivum L.) çeşitlerinde farklı sıra arası ve tohumluk miktarının tane verimi ve verim unsurlarına etkileri. Tarım Bilimleri Dergisi- Journal of Agricultural Sciences 14(1): 29-37

Beğen F (2012). Yüksek lif içerikli bisküvi üretiminde lüpen (Lupinusalbus L.) kepeği kullanımı üzerine bir araştırma. Yüksek lisans tezi, Selçuk Üniversitesi Fen Bilimleri Enstitüsü (Basılmamış), Konya

Beta T, Nam S, Dexter J E \& Sapirstein H D (2005). Phenolic content and antioxidant activity of pearled wheat and roller-milled fractions. Cereal Chemistry 82(4): 390-393

Bilgiçli N, İbanoğlu Ş \& Herken E N (2007). Effect of dietary fibre addition on the selected nutritional properties of cookies. Journal of Food Engineering 78(1): $86-89$

Collar C (2008). Novel high-fiber and whole grain breads, In: Hamaker B (Eds), Technology of Functional Cereal Products, Woodhead Publishing Limited Cambridge, UK, pp. 336-361

Demir M K (2010). Bazı fiziksel uygulamaların tam buğday ununun depolama stabilitesi, ekmekçilik kalitesi ve besinsel özelliklerine etkisi üzerine araştırmalar. Doktora tezi, Selçuk Üniversitesi Fen Bilimleri Enstitüsü (Basılmamış), Konya

Düzgüneş O, Kesici T, Kavuncu O \& Gürbüz F (1987). Araştırma ve Deneme Metodları (İstatistiksel Metodlar1-II), Ankara Üniversitesi Ziraat Fakültesi Yayın No: 1021, Ankara

Elgün A \& Demir M K (2008). Tam buğday unu ve fonksiyonel özellikleri. Türkiye 10. Gıda Kongresi: 21-23 May1s, Erzurum, s. 49-52

Elgün A \& Ertugay Z (1995). Tahıl İşleme Teknolojisi, Atatürk Üniversitesi Ziraat Fakültesi Yayınları, No:718, Erzurum

Francis F J (1998). Colour Analysis, In:Nielsen S S (Eds), Food Analysis, An Aspen Publishers, Gaithersnurg, USA., pp. 599-612

Graf E, Empson K L \& Eaton J W (1987). Phytic acid: A natural antioxidant. The Journal of Biological Chemistry 262(24): 11647-11650
Haug W \& Lantzsch H J (1983). Sensitive method for the rapid determination of phytate in cereals and cereal product. Journal of the Science of Food and Agriculture 34(12): 1423-1426

ICC (2002). International Association for Cereal Science and Technology, ICC- Vienna

Jeltema M A, Zabik M E \& Thiel L J (1983). Prediction of cookie quality from dietary fiber components. Cereal Chemistry 60(3): 227-230

Kissell L T, Pomeranz Y \& Yamazaki W T (1971). Effects of flour lipids on cookie quality. Cereal Chemistry 48 : 655-662

Levent H U (2005). Farklı kaynaklardan elde edilen besinsel liflerin bisküvi kalitesi üzerine etkilerinin karşılaştırılması. Yüksek lisans tezi, Selçuk Üniversitesi Fen Bilimleri Enstitüsü (Basılmamış), Konya

Meuser F, Brummer J M \& Seibel W (1994). Bread varieties in central Europe. Cereal Food World 39(4): 222-230

Özkaya B (2004). Ekmeğin fitik asit miktarına çeşit ve ekstraksiyonun etkisi. Ankara Üniversitesi Bilimsel Araştırma Projeleri, Proje No: 2002-07-11-064, Ankara

Özkaya B \& Demir Z (1999). Unların bisküvilik özelliklerine değişik kaynaklı bitkisel liflerin etkileri. Un Mamulleri Teknolojisi 8(1): 58-64

Singleton V L \& Rossi J A (1965). Colorimetry of total phenolics with phosphomolybdic-phosphotungstic acid reagents. American Journal of Enology and Viticulture 16(3): 144-158

Slavin J L (2000). Mechanisms for the impact of whole grain foods on cancer risk. Journal of American College of Nutrition 19(3): 300-307

Srivastava A K, Sudha M L, Baskaran V \& Leelavathi K (2007). Studies on heat stabilized wheat germ and its influence on rheological characteristics of dough. European Food Research and Technology 224(3): 365-372

Sudha M L, Srivastava A K \& LeelavathiK (2007a). Studies on pasting and structural characteristics of thermally treated wheat germ. European Food Research and Technology 225(3-4): 351-357

Sudha M L, Vetrimani R \& Leelavathi K (2007b). Influence of fibre from different cereals on the rheological characteristics of wheat flour dough and on biscuit quality. Food Chemistry 100(4): 1365-1370

Uzunkaya D F \& Ercan R (1999). Hamburger ekmeklerinde yüksek lifli katkıların kullanım olanakları. Gida 24(6): 369-377

Yavaş Y (2012) Hemiselülaz enziminin tam buğday unlu keklerin fiziksel özellikleri üzerine etkisi. Yüksek lisans tezi, İstanbul Teknik Üniversitesi Fen Bilimleri Enstitüsü (Basılmamış), İstanbul 